\title{
The Captain's Psychological Problems and the Process of His Withdrawal from Reality in Strindberg's TheFather
}

\author{
Liem Satya Limanta \\ English Department, Faculty of Letters, Petra Christian University, \\ 121-131 Siwalankerto, Surabaya 60236, East Java, Indonesia \\ e-mail: satya@peter.petra.ac.id \\ Chris Andre Sutanto \\ e-mail: chris_andre_sutanto@hotmail.com
}

\begin{abstract}
This paper will reveal the psychological complications of the Captain, the main character of Strindberg's The Father. The writers are interested in inquiring what kinds of fixation and anxiety that the Captain undergoes, how he tries to solve his anxieties, and how he finally withdraws from reality. Therefore, a psychological approach with Freud's psychoanalytic theory is utilized in dissecting the complexity of the mental condition of the Captain.
\end{abstract}

Key words: fixation, anxiety, defense mechanism

The Father has captivated the writers' interest due to its intriguing, accelerating tension between the complex and neurotic characters, especially the Captain, from one act to another. The plot has been designed so intensely, while the war between the sexes is subtle yet mentally destructive. These qualities have thus highlighted The Father among Strindberg's plays as a canonized literary work that unravels spellbinding psychological revelations. Garnered with the Gold Medal of the Swedish Academy in 1964, Michael Meyer's Methuen-published translation of The Father, which is widely performed hitherto, remains the writers' chosen rendition of the analyzed literary work.

One apt theory of psychology with which to scrutinize the Captain's mental problems is Freud's psychoanalytic theory. Aside from suffering from acute psychic disturbance, the Captain actually lacks childhood gratification. This kind of lack, according to psychoanalysis, inevitably will trigger a fixation that urges an individual to continuously endeavor to 
obtain the unfulfilled satisfaction (Pervin, Cervone, \& John, 2005, p. 123). Another interesting issue to highlight is the Captain's irrational fears, which refer to anxiety in psychoanalysis (Hall, 1979), toward his wife and the women of the house, as is portrayed in his delusional statement addressing himself as acting slave-like among the females. Thus, several psychoanalytic theories including fixation, anxiety, and the ways to deal with them, such as sublimation and defense mechanism, are utilized in order to unveil the Captain's mental condition.

\section{THE CAPTAIN'S FIXATIONS AND ANXIETIES}

Two kinds of neuroses that the Captain suffers are fixations and anxiety, which are both incited by traumatic experiences. Fixations have become the Captain's pattern of behavior in his adult life. However, his fixations have developed into an anxiety since there has been much obstruction in the fulfillment of his infantile gratification. Furthermore, the existence of anxiety may signal danger to the ego. If it is unresolved, nonetheless, the anxiety will pose much threat to the sanity of the mind.

\section{The Captain's Fixations}

The lack of parental care during childhood and the sister's superiority over him are the major traumas that bring about the Captain's fixations. The striking psychopathological outbreaks of the fixations varying from oral, anal, and phallic are mostly apparent in his quarrel with the women of the house: Laura, the nurse, and Bertha.

\section{The Captain's Oral Fixation}

The first major excitation area of children below two years old lies in the mouth, which Freud names as the oral stage. The mother's breast is acknowledged as the chief source of pleasure in this stage since it provides gratifying oral activity as well as nourishing milk for the infants (Hall, 1979). Either insufficient or excessive gratification, nonetheless, causes the presence of an oral personality in one's adult life. An oral person tends to take delight in chewing gum, eating, smoking, and kissing, all of which focus on reclaiming typical infantile satisfaction relating to the mouth. An intellectual may also convey oral associations through speech, as in: one is 
given "food for thought," asked to "incorporate" reading material, and told to "regurgitate" what has been learned on exams (Pervin, Cervone, \& John, 2005, p 102).

The Captain's initial trauma, which corresponds to his oral fixation, relies on the sole representational figure that possesses the ultimate oral pleasure, the mother. While a mother may supply a combination of nourishment and gratifying oral motion through breastfeeding, this ideal fostering does not take place in the Captain's life.

CAPTAIN. ...My mother was my enemy. She didn't want to bring me into the world because my birth would cause her pain. She robbed my first embryo of its nourishments, so that I was born half-crippled. (Strindberg, 2000, p. 74)

Beyond the plausibility of how he gains evidences for his accusation, this statement unveils clues to the Captain's unfulfilled gratification. He not only abhors his mother subjectively but also suspects her of failing to supply nourishment to his embryo. Even though he has not addressed any explicit utterances denoting oral activity, the lack of nourishment may indicate implied evidence to the existence of oral fixation.

Regression to oral gratification in adult ages is vividly pronounced when the Captain is at the edge of consciousness. Margaret, the nurse, has put him in a straitjacket; he rebels for a minute, then he subdues.

CAPTAIN. Come and sit beside me here, on the chair. That's right. May I rest my head in your [Margaret] lap? So. That's warm! Bend over so that I can feel your breast. Oh, it is sweet to sleep at a woman's breast, whether a mother's or a mistress's, but sweetest at a mother's! (p. 76)

The desire to suckle a mother's breast apparently occupies the Captain's mind, with Margaret acting out to be the substitute mother. He clearly longs for certain oral motions carried within a task such as breastfeeding, which would be accomplished if Margaret simply bends over onto him. Oral fixation shows the Captain's distinct urge to suck on a mother's breast once more. 
A quarrel between the Captain and Bertha, his daughter, in the last act evokes bizarre instances that have close association to oral fixation.

CAPTAIN. ...You see, I'm a cannibal, and I want to eat you. Your mother wanted to eat me, but she couldn't. I am Saturn, who ate his children because it had been prophesied that otherwise they would eat him. To eat or be eaten! That is the question. If I don't eat you, you will eat me, and you have already shown me your teeth. (p. 71).

The choice of dictions uttered certainly exposes a lucid oral association. He imagines himself as a "cannibal," a descriptive adjective which describes the habit of eating the same species. The word "eat" has been used in abundance to express the notion of obsession and domination. He demands to have the absolute control over his daughter, yet Laura, his wife, intends to vie and obtain the authority instead.

The Captain also juxtaposes an allusion to Saturn, a Roman god, with the previous oral association. Saturn, alias Cronus in Greek mythology, is famous for avenging his mother's marital jealousy by cutting off his own father's genital. Fearing to end up in a similar fate to his father, Saturn confronts it all by devouring his child (Morford \& Lenardon, 1985). Eating then represents a way to dominate the others. Altogether, the Captain abuses Shakespeare's Hamlet's famous quotation to sum up his oral fixation, "To eat or be eaten! That is the question."

\section{The Captain's Anal Fixation}

The anal stage comes at about the age of two or three with the major excitation area of anus and in the movement of feces through the anal passageway. An intriguing inner-conflict distinguishes anal gratification to be equivocal, in which either retention or elimination of the feces confers different pleasure. Retaining the feces leads to stimulated, gratified mucous membranes of the anal; meanwhile, the later brings relief to the stomach after expulsion (Pervin, Cervone, \& John, 2005, p. 102).

In a broader sense, a child can have much satisfaction when releasing fecal material by often going to the toilet and by the other way around, of retaining it. The existence of disciplinary toilet training orchestrated by authoritative figures based on cleanliness, control, and responsibility, however, threats the child's dual pleasure (Hall, 1979). Natural rebellion 
with the act of retention is often executed by children, as if they prefer holding the power of determination over personal pleasure in their own capacity. Excretion, thus, symbolizes the exercise of power, and anal fixation in adult life has a tenacious correlation to authoritative figures.

The first exercise of power experienced by the Captain is due to his sister's superiority. Her suppressive authority has become one traumatic moment related to the anal fixation. This can be seen from the Captain's statement: "My sister was my enemy, when she taught me that I was her inferior" (Strindberg, 1988, p. 74).

The Captain's forced inferiority is in contrast with a child's being active in deciding his anal pleasure. Pronouncing his sister as an enemy, the Captain's loss of power and control turns out to be the traumatic experience that haunts his mind.

One of the anal personalities is having the confusion over submitting and rebelling. This idea is based on the child's attitude toward toilet training. Submission means that the child lets his control over things be taken away; while rebellion means that the child retains his power. Submission is the symbol of elimination of the fecal material; while rebellion is the retention of the feces. Both activities, nevertheless, contribute anal pleasure to the child (Pervin, Cervone, \& John, 2005, p. 123). The Captain also indulges his anal gratification by doing both actions simultaneously in his adulthood.

CAPTAIN. When you [Laura] and I became one, I thought I was making myself whole; so I let you rule; and I who, in the barracks, among the soldiers, gave commands, was, with you, the one who obeyed. I grew up at your side, looked up to you as though to a superior being... (Strindberg, 2000, p. 60)

He retains his power while he is with the soldiers, but he lets his power be taken by his wife at home. The Captain as the superior among the soldiers is inferior to his wife. Therefore, he thinks that he is making himself "whole" when he is with his wife, meaning that he is completing his unfulfilled anal gratification. In addition, as long as the Captain still has the opportunity to control things, he would have anal gratification.

Another anal personality that the Captain shows is the anxiety over waste and loss of control. Laura cuts off the opportunity for him to rule and retain his power in the barracks. 
CAPTAIN. ... Now I have confiscated some letters addressed to you. ... It is clear from these letters that for some time you have been turning all my former friends against me by spreading a rumour concerning my sanity. And you've succeeded, for now hardly one of them, from my commanding officer to my cook, regards me as sane. (pp. 55-56)

The Captain is the superior and the dominant one in the barracks. He controls his commanding officer, his cook, and so on. Laura, unfortunately, has changed this situation. She intercepts all of his letters and spreads the rumor that her husband is no longer sane. As a result, the officers and even the cook do not follow what the Captain says any more. They believe that he is insane. The Captain loses his power and dominance over them. Laura, then, has become the strict authoritative figure who interferes in her husband's anal pleasure. Afterwards, the Captain rebels against Laura by confiscating her letters. His action, nevertheless, does not regain his control back over his soldiers in the barracks.

Laura also does not let him have any chance to rule at home. The Captain always believes that as a father he is obliged and has the right to decide what is best for his daughter. Laura challenges her husband's rights as a father by lying that "Bertha is my child, not yours!" (p. 45). Her husband, then, gets frustrated over losing his control and power over his daughter.

CAPTAIN. ... If the child is not mine, I have no rights over her, and want none - and that is all that you want. Isn't it? Do you want something else too? Do you want to retain your power over the child, but to keep me here as the breadwinner?

LAURA. Power? Yes. What has this life-and-death struggle been for if not for power?

CAPTAIN. ... Take her away and you cut short my life. (p. 58)

The Captain loses his dominance in the barracks. At home, he believes that he has the power over his daughter. Now, Laura has obstructed his belief as a father with her lies. She blatantly opposes him, becoming a terrible authoritative figure over him. Finally, the Captain expresses his anal fixation by saying that taking over his control over his daughter is the same as cutting short his life. 


\section{The Captain's Phallic Fixation}

In the phallic stage, at the age of four or five, the major excitation is on the genitals. A male child finds his gratification, especially, in the erection of the genital. The erection of the genital naturally symbolizes masculinity. The increased interest in the genital for a male child is usually followed by the realization that the female lacks a penis (Pervin, Cervone, \& John, 2005, p. 103). This kind of realization will, later, lead to "castration anxiety."

If the gratification during the phallic stage is inadequate or overwhelming, phallic fixation will occur. A phallic male character has the tendency to emphasize his masculinity and potency. Whereas success for the oral person means "I get," and success for the anal person means "I control," success for the phallic male means "I am a man." The success also means that he is "big" in the eyes of others. A phallic male also has an exhibitionistic quality in order to deny the idea of castration, like the female who lacks a penis (p. 124).

The Captain's effort to sexually dominate his wife has exposed the traces of phallic fixation in the adult life. Laura always considers that her influence over the Captain is like a mother to her son. However, the Captain tries to prove that he is a man by taking her sexually.

LAURA. Do you remember, it was as your second mother that I first entered your life? ... I loved you as my child. But, do you know - I suppose you noticed it - every time your feeling towards me changed, and you approached me as my lover, I felt bashful ... The mother became the mistress - ugh!

CAPTAIN. Yes, I saw it but I didn't understand. I thought you despised my lack of masculinity, and I wanted to win you as a woman by being a man. (Strindberg, 1988, p. 60)

When his wife appears as a mother, a superior being, the thought of lack of masculinity occupies the Captain's mind. He needs to assure himself and his own wife that he is a real man, a masculine one. Having sexual intercourse with his wife is his way of exhibiting his potency and masculinity.

The Captain also overemphasizes his being a man toward the doctor who comes to his house. Laura has told the doctor that her husband is 
mentally unfit. Then, the doctor tries to get the other version of the story by asking what has really happened to the Captain. Unfortunately, the Captain refuses his inquisition by saying:

CAPTAIN. ... If I were not a man I would have the right to accuse or, as the polite phrase is, to lay a complaint. Then I might perhaps be able to give you a complete diagnosis of my illness, and, what is more, its history. But, unfortunately, I am a man, and so I can only, like a Roman, fold my arms across my breast and hold my breath until I die. Good night.

DOCTOR. Captain! If you are ill, it cannot be any reflection on your honour as a man to tell me the truth. I must hear both sides. (p. 55)

As a man, the Captain believes that he cannot complain about his wife and tell the doctor about his illness. In fact, the model of a masculine man that he has in his mind is like a Roman, who folds his arms and holds his breath until the day he dies. Though the doctor declares that by telling what has really happened does not affect the Captain's being a man, he still persists to keep quiet. A man is someone who can keep his own affairs.

The Captain's Anxieties

Anxiety is a painful emotional experience derived from the individual's traumatic experiences. Anxiety is another neurosis besides fixation, and it is synonymous with the emotion of fear. It exists as a signal of danger to the ego. Whenever an anxiety threatens an individual, the person's ego will employ some strategies, such as displacement, sublimation, defense mechanism, and so on, to reduce the tension rendered by the anxiety (Hall, 1979, pp. 79, 85).

There are three types of anxiety: reality or objective anxiety, neurotic anxiety, and moral anxiety. In reality anxiety, the source of danger lies in the external world. One might be afraid of the presence of certain objects or environmental conditions, which are mostly acquired during the person's lifetime. In neurotic anxiety, the threat resides in one's id. The free-floating type of neurotic anxiety happens when one expects that something dreadful might occur. The third, moral anxiety has the source of threat from the superego. Since killing is sinful, one might feel terribly guilty and anxious after having done such matter (pp. 63-69).

The women of the house solely act as the source of danger that renders anxieties, both reality and neurotic, to the Captain's psychological 
condition. They often obstruct the Captain's effort in gaining his infantile gratification. They even make him feel helpless at the end, and the fact that their sex is female has profoundly intensified his fear.

The Captain exposes his neurotic anxiety through the free-floating type, believing that something wrong will happen. The paternity doubt rendered by Laura is the second source of danger. It triggers neurotic anxiety, the panic reaction type. The Captain has always believed that he is the father of Bertha, his own daughter. However, his belief seems to crumble when Laura lies to him that Bertha is not his child. During his panic, he tries to kill Bertha, as the way to have the absolute control over her.

\section{The Captain's Reality Anxiety}

The source of tension centralized in the women of the house causes the Captain's reality anxiety. The women of the house have always triggered the Captain's anxiety whenever their decision influences his exercise of power. As an anal and phallic person, he has the need to have dominance over the others and to show his potency and masculinity. Unfortunately, the women have always different opinions that compel him to obey. Bertha's future is the chief problem that separates the Captain and the women into two opposing parties. In the opening scene, the Captain consults about Bertha's upbringing to his brother-in-law. It has been a difficult matter since the women have made their own decision on the case.

CAPTAIN. ... My mother-in-law wants to make her a spiritualist, Laura wants her to be a painter, her governess wants her to be a Methodist, old Margaret wants her to be a Baptist, and the maids are trying to get her into the Salvation Army. Well, you can't patch a soul together like a damned quilt. I have the chief right to decide her future, and I'm obstructed whichever way I turn. I've got to get her out of this house. (Strindberg, 1988, p. 30)

The women, Laura, Laura's mother, Bertha's governess, old Margaret, and even the maids, are trying to get Bertha to follow what they want her to be. However, the Captain thinks that he is actually the one who is responsible for making any decisions about his daughter's future. He wants Bertha to study in the town and learn to be a teacher. His control over Bertha, 
unfortunately, is obstructed by the women, especially Laura. The Captain argues this matter while bringing up the law as the supporting fact.

CAPTAIN. The law states that a child is to be brought up in her father's faith.

LAURA. And the mother has no say in the matter?

CAPTAIN. None. She has sold her birthright by legal contract, and has surrendered all her claims. In return, the husband supports her and her children.

LAURA. So she has no rights over her own child?

CAPTAIN. None whatever. Once you have sold something, you can't get it back and keep the money. (p. 34)

The Captain quotes the law as the authoritative basis that demands every father to convert the children to his faith. It also orders every husband to support his wife and children, while the wife surrenders her rights over her children to her husband in return.

Laura's persistence in obstructing her husband's control over their daughter has augmented her husband's anxiety intensely. She challenges his belief as Bertha's father.

LAURA. ... Suppose I am telling you the truth now, when I say to you: 'Bertha is my child, not yours!' Suppose - !

CAPTAIN. Stop!

LAURA. Just suppose. Your power over her would be ended.

CAPTAIN. If you could prove I was not the father.

LAURA. That wouldn't be difficult. Would you like me to?

CAPTAIN. Stop it! At once!

LAURA. I'd only need to name the true father, and tell you the time and place. For instance - when was Bertha born? Three years after our marriage-

CAPTAIN. Stop it, or - !

LAURA. Or what? All right, I'll stop. But think carefully before you take any decisions...

CAPTAIN. God - I could almost weep - ! (pp. 45-46)

Laura has been able to "turn the table," making the Captain almost weep. She tells her lie that Bertha is not her husband's child. Furthermore, the 
doctor tells Laura that a person who is certified as mentally disturbed will lose all of his civic and family rights. This idea encourages Laura to find a way to cut off her husband's rights and take over the control over her daughter.

LAURA. Yes. And tomorrow I shall have it [the rights over the daughter] legally, when I have you certified. ... By this letter, an attested copy of which I have deposited with the authorities.

CAPTAIN. What letter?

LAURA (moving backwards toward the door). Yours! The one you wrote to the doctor ... You have done your job as a father and a breadwinner. Now you are no longer needed, and you can go...

The CAPTAIN goes to the table, takes the burning lamp and throws it at LAURA, who has retreated through the door. (p. 62)

Laura has got a letter written by her husband stating that he is mad. She has the power to certify her husband as mentally ill. In other words, Laura, as one of the women, has defeated the Captain in terms of having the dominance over the daughter. This situation, consequently, renders anxiety. Laura has made the Captain helpless to put up any fight against the situation. He is "impotent," his masculinity has been ruled out by a female. As a result of both the thwarted anal gratification and the belittled manliness, the Captain reacts against his anxiety by eliminating Laura, his source of tension. The Captain's throwing a burning lamp to his wife is his act of elimination (though it misses her).

\section{The Captain's Neurotic Anxiety}

The Captain occasionally confides his neurotic free-floating anxiety to the pastor and the nurse. During his conversation with his brother-in-law, the pastor, the Captain shares his fear of the women in the house.

PASTOR. You've too many women running your home.

CAPTAIN. You needn't tell me that. It's like a cage full of tigers - if I didn't keep a red-hot iron in front of their noses, they'd claw me to the ground the first chance they got... (p. 30) 
The Captain compares the women with tigers. If he does not keep the women under control, they would find a way to rule him out. A freefloating display of neurotic anxiety happens when someone fears that something bad might happen to him although it is actually his fear of his id controlling his ego. The Captain is afraid that, one day, his id might take over his ego, preventing it from any interaction with the outer world. If this happens, he will lose control of his actions or, even, be helpless to do anything. Then, the women of the house, the Captain thinks, would be able to "claw him to the ground" or dominate him.

Besides his brother-in-law, the Captain also exposes his free-floating neurotic anxiety to his nurse. When Margaret comes to talk about the problem between the Captain and his wife, he suddenly asks his nurse to stay on his side instead of on his wife.

CAPTAIN. ... But I'm telling you, Margaret - if you desert me now, you are committing a sin. A web is being spun around me here, and that doctor is not my friend.

NURSE. Oh, Mr. Adolf, you think bad of everyone... (p. 41)

CAPTAIN. ... Help me. I feel something is going to happen here - I don't know what, but there's something evil threatening - (p. 42)

The Captain thinks that the women of the house are going to trap and make him helpless, like a fly in a spider web. He needs his nurse to stay on his side, since the doctor, as a newcomer of the house, has also deserted him. Though Margaret has coaxed him saying it is only his thought, the Captain persists that he feels something evil threatening. What the Captain fears actually is his own id. His id might dominate his ego so that it is helpless to handle the situation in the real world. Once again, the Captain has shown his free-floating display of neurotic anxiety over the women of the house.

\section{THE CAPTAIN'S WAYS IN DEALING WITH THE ANXIETIES}

The Captain's withdrawal from reality is the end of the process of his ego dealing with his anxieties. His ego executes two main methods to reduce the tension from his anxieties, that is, sublimation and defense mechanism. Sublimation helps to reduce his anxiety toward the women of the house by heightening the phallic infantile gratifications. It allows the Captain to reveal his intellectual potency through conducting research 
about meteorites. Next, defense mechanisms such as projection and repression decrease the Captain's anxieties. Projection, the prior, often encourages him to project out and reckon his internal fear as an external fear. The latter, repression, is employed to repress the Captain's painful memory. In the final scenes of the play, the women succeed in seizing the Captain in a straitjacket, which apparently boosts his anxieties to climax. $\mathrm{He}$ is physically helpless to reduce any of his tension so that the ego has to repress his consciousness, as the last resort to salvage his ego from the threatening reality.

\section{Sublimation}

The Captain has exerted sublimation when conducting researches in order to reveal his intelligence and gain honor for himself. As a phallic character, he needs to show his potency and masculinity to others. Laura and the other women of the house, unfortunately, always get involved in most of his cases and thwart his capability of making decision.

CAPTAIN. No, you [Laura] were always the one who has the upper hand. You could hypnotize me so that I neither saw nor heard, but only obeyed. You could give me a raw potato and make me think it was a peach, you could force me to admire your stupid whims as strokes of genius, you could have driven me to crime, yes, even to vice. For you lacked intelligence, and instead of following my advice you did as you wanted. But when, later, I awoke and looked about me and saw that my honour had been sullied, I wanted to wipe out the stain through a noble action, a brave deed, a discovery, or an honourable suicide. I wanted to go to war, but I couldn't. It was then that I turned into science... (p. 61)

Laura has been successful in dominating her husband. The Captain submits to her the first time, but then he realizes that he needs to rebel. He believes and wants to show that he is more intelligent than she is. The Captain's ego displaces his unfulfilled need with science. He becomes a distinguished scientist whose intellectual potency is respected and praised by others. He has even discovered carbon as the evidence of organic life (p. 39). His coming to science is a form of sublimation, a way of the ego to reduce the anxiety. It occurs when one's substitute object that corresponds to one's 
gratification is related to cultural activity (Pervin, Cervone, \& John, 2005, p. 95). In this case, the research project is the cultural activity.

Unfortunately, the Captain's sublimation fails to deal with his anxiety. His scientific project has been obstructed by Laura. She intercepts the mails from and to the Captain.

CAPTAIN. ... This evening I went to the post office and collected my letters. It is evident from them that you have been intercepting both my outgoing and my incoming correspondence. The resultant waste of time has virtually destroyed the value of my researches.

LAURA. I was acting from kindness. You were neglecting your duties for this work.

CAPTAIN. You were not acting from kindness. You feared that some day I might win more honour through these researches than through military career, and you were determined that I should not win any honour, because that would throw into relief your insignificance. (Strindberg, 1988, p. 56)

Laura has thwarted her husband's sublimation. She does not let him have the chance to exhibit his intellectual potency. This condition causes the Captain's anxiety to persist.

CAPTAIN. ... Now, when I should stretch out my hand to receive the fruit of my labour, you [Laura] chop off my arm. Now I am without honour, and I cannot go on living, for a man cannot live without honour. (p. 61)

The Captain confesses that being unable to continue his project affects his way of living. His research should have been a way to reduce his anxiety toward women. However, the latest situation shows that he has suffered much more from anxiety since his sublimation has been spoilt by the same source of tension, Laura, one of the women.

\section{Defense Mechanism}

Since the sublimation fails, the Captain requires defense mechanism as the other way to deal with his persistent anxiety. The mechanism relieves the anxiety by distorting the truth and excluding the anxiety from 
awareness. Therefore, defense mechanism is considered as unrealistic approach to problem-solving, for it may turn a person away from reality (Hall, 1979).

\section{Projection}

Projection copes with the anxiety caused by the women of the house through the means of the paternity doubt. The Captain projects his fear out to the doctor and his brother-in-law. First, the Captain instills his fear of paternity doubt to his brother-in-law.

CAPTAIN. ... Tell me, Jonas [the brother-in-law], do you believe that you are your children's father? I remember you used to have a tutor living with you whom people talked about. Such beautiful eyes, they said he had.

PASTOR. Adolf [the Captain]! Take care, now - !

CAPTAIN. Put your hand under your hair and see if you don't feel a couple of bumps there! I'm blessed if he hasn't gone pale! Yes, yes, it was only talk - but, my God, how they talked! (Strindberg, 1988, p.

69)

The Captain mocks his brother-in-law, saying that he might not be the father of his children. The Captain adds that people always talk about a handsome tutor who once lives with his brother-in-law. He seems to enjoy projecting his fear toward his brother-in-law. Furthermore, the Captain continues his mocking toward the doctor of the house.

CAPTAIN. ... But we're all objects of ridicule, we husbands. Isn't that true, Doctor? How about your marriage couch? Didn't you have a lieutenant billeted on you? Wait, now, let me guess - wasn't he called - ? (Whispers in the DOCTOR's ear.) You see, he's gone pale too! Don't cry, now. She's dead and buried, and what's done can't be done again! I knew him, though - now he's a - look at me, Doctor! - no, in the eyes! - a major in the Dragoons. By God, I believe he's [the doctor] grown horns too! (p. 69)

The Captain does the same thing toward the doctor. He encourages the doctor to suspect the lieutenant who once stays in the doctor's house. Then, 
the Captain tries to mock the doctor again, saying that his wife is dead and he cannot change anything that has happened. The Captain takes a delight over his projection when he sees that the doctor's face has turned pale. He has lessened his anxiety by putting his fear away at the moment and reckoning it as an external fear.

\section{Repression}

The last way that the Captain uses to deal with his anxieties that leads to his withdrawal from reality is repression. To deal with his reality anxiety regarding Laura's control over the daughter, the Captain represses his memory over his mad action that happened before Bertha comes to talk to him.

BERTHA. Are you ill, father?

CAPTAIN (looks up dully). I?

BERTHA. Do you know what you've done? Do you know you threw a burning lamp at mother?

CAPTAIN. Did I? (p. 70)

The Captain has repressed his memory, since the idea of one throwing a burning lamp toward his mother figure might be prohibited by his superego. As a result, he questions himself whether he has done what Bertha accuses. Repression succeeds in decreasing his anxiety, yet it also falsifies the reality.

The usage of repression has also led the Captain to undergo a withdrawal from reality. This occurs after the women have made him physically helpless to rebel against their lies in terms of paternity doubt.

LAURA. Do you want to see your child, Adolf? Speak!

CAPTAIN. My child? A man has no children. Only women have children, and so the future belongs to them, while we die childless. (p. 76)

In the end, the Captain does not question any more whether he is the father of his daughter. He withdraws from the struggle, stating that no man owns any children. The women's influences have unquestionably overpowered 
his ego. Soon after, the Captain bids goodnight to Margaret and suddenly faints, losing consciousness.

CAPTAIN. ... I'm so tired, so tired. Good night, Margaret. Blessed be thou amongst women -

He raises himself, but falls with a cry in the NURSE's lap.

LAURA goes left, and calls the DOCTOR, who enters with the PASTOR.

LAURA. Help us, Doctor, if it isn't too late. Look, he's stopped breathing!

DOCTOR (takes the CAPTAIN's pulse). He has had a stroke. (p. 76)

What is happening on the level of consciousness should have posed overwhelming painful excitation to the Captain's ego. Repression appears to be the last way of the ego to save him from the overbearing tension. It shuts down the Captain's consciousness, taking his ego far away from the painful reality. The doctor, afterwards, diagnoses the Captain as having a stroke. His mind has eventually withdrawn from the threatening reality.

\section{CONCLUSION}

The analysis above confirms that the Captain suffers from oral, anal and phallic fixation. All these fixations have a regressive pattern of behavior that seeks to gain infantile gratifications. The analysis also explains that the Captain undergoes two kinds of anxiety, reality and neurotic anxiety, both incited by the women of the house. The Captain's ego executes sublimation at first in order to deal with his anxiety over the women of the house, especially Laura. Next, it also employs two types of defense mechanism to manage the anxiety. Projection sees the Captain's neurotic anxiety, the women's lies over paternity doubt, as an external instead of internal fear. Second, the Captain has repressed his memory over throwing a burning lamp toward his wife. When he is helpless being tightened up in a straitjacket by the women, repression saves his ego away from overpowering tension. It shuts down his consciousness since what is happening in the reality is threatening his ego. In other words, repression has withdrawn his ego from reality, resulting in the condition regarded by the doctor of the house as a stroke. 


\section{REFERENCES}

Hall, C. S. (1979). A primer of Freudian psychology. New Jersey: Nal Penguin.

Morford, M. P. O., \& Lenardon, R. J. (1985). Classical mythology. New York \& London: Longman.

Pervin, L. A., Cervone, D., \& John, O. P. (2005). Personality theory and research ( $9^{\text {th }}$ ed.). Toronto: John Wiley \& Sons.

Strindberg, A. (2000). The father. Plays: One (M. Meyer, Trans.). London: Methuen Publishing. 